\section{AMERICAN-EURASIAN JOURNAL OF SUSTAINABLE AGRICULTURE}

ISSN: 1995-0748, EISSN: 1998-1074

2019, volume (13), issue (3): pages (10-20)

DOI: 10.22587/aejsa.2019.13.3.2

Published Online in September http://www.aensiweb.com/AEJSA/

\title{
Mineralo-chemical study of Titanium and Zirconium as indicators for soil profile uniformity and development
}

\author{
N.M.A. Bahnasawy ${ }^{1}$, M.M. El Kady ${ }^{2}$ and A.M. Elwa ${ }^{1}$ \\ ${ }^{1}$ Soil Chemistry and Physics Department,, Desert Research Centre, El-Matariya 11753, Cairo, Egypt
}

${ }^{2}$ Pedology Department, Desert Research Centre, El-Matariya 11753, Cairo, Egypt

Received date: 12 July 2019, Accepted date: 28 September 2019, Online date: 14 October 2019

\author{
Address for Correspondence: \\ M.M. El Kady, Pedology Department, Water Resources and Desert Soils Division, Desert Research Centre, El-Matariya 11753, Cairo, \\ Egypt
}

Copyright ( 2019 by authors and American-Eurasian Network for Scientific Information. This work is licensed under the Creative Commons Attribution International License (CC BY). http://creativecommons.org/licenses/by/4.0/

\section{(c) (i) Open Access}

\begin{abstract}
The consciousness of soil development along with assessment uniformity of its parent materials is considerably needed for sustainable use of land resources, and adopt suitable techniques for land use management. Thus, the main objective of the current article is to shed light on and determine the total chemical content of titanium (Ti) and zirconium ( $\mathrm{Zr}$ ) elements and their relation to the soil's mineralogical composition as indicators for investigating soil profile uniformity and evolution. Twenty soil samples were collected from successive strata of five pedons which were selected within two geomorphological units constitute some soils south-east portion of El-Qattara depression $\left(2^{\circ} 33^{\prime} 30^{\prime \prime}\right.$ to $28^{\circ} 36^{\prime} 00^{\prime \prime} \mathrm{E}$; $3^{\circ} 05^{\prime} 33^{\prime \prime}$ to $30^{\circ} 09^{\prime} 10^{\prime \prime} \mathrm{N}$; 25 $\mathbf{k m}^{2}$ ). Soils could be classified into deep coarse-textured; Typic Torripsamments. Total (Ti) ranged from 139.42 to 1736.8 while total $(\mathrm{Zr})$ was $<113 \mathrm{mg} \mathrm{kg}^{-1}$ in the studied soils. Frequency distribution of light minerals referred to the sovereignty of quartz followed by feldspars. Heavy minerals are dominated by non-opaques represented in amphiboles, pyroxenes, resistant and parametamorphic minerals. The correlation coefficient (r) between Titanium with Rutile, Titanium with Titanite, and Zirconium with Zircon (0.316), (0.151), and (-0.107), receptivity. Based on the result, pyroboles percentages were higher than resistant minerals proportions, indicating that the investigated soils are immature and weakly developed. Microscopic graphs clarified that sediments which constitute the studied soils are mostly transported by water from near source. Moreover, irregular distribution with depth for uniformity ratios, index figures, weathering ratios of the identified minerals along with ( $\mathrm{Zr}$ ) and (Ti) contents has reflected heterogeneity of soil parent materials forming the research area. These results have to put in consideration of the land use planner for agriculture to determine the most suitable soil management for sustaining those kinds of land resources for a more extended time of productivity.
\end{abstract}

\section{KEYWORDS}

Heavy minerals, Titanium, Zirconium, Parent material uniformity, soil development, Pedogenesis, Typic Torripsamments, El-Qattara depression.

\section{INTRODUCTION}

Assessment of pedogenic situation changes in soils encompasses the rapprochement of the solum with the parent material. Within many investigations, if no explicit irregularity exists during the deposit from which the soil has developed, pedologists presume that the soil has formed within a comparatively uniform material. Using stable minerals or of their constituent elements supplies a way of fixing the original uniformity of a deposit, and appraisement of soil development [4]. Titanium (Ti) and Zirconium (Zr) as weathering indices have granted a particular prove of their appropriateness in pedogenesis researches. Due to $\mathrm{Ti}$ and $\mathrm{Zr}$ are concentrated in soils than in the parent rocks, they are useful for soil development investigations [7]. Soil scientists considered evidence of titanium and zirconium distribution and morphology within their pedogenesis investigations on Texas Gulf Coastal Plain. They noticed that there are no marked discontinuities in Ti contents with depth [20]. 
Spanish researchers analyzed $\mathrm{Ti}$ and $\mathrm{Zr}$ in ten weathering and pedo-genetic soil profiles developed on granitic rocks from NW Spain. They found that concentrations of $\mathrm{Ti}$ and $\mathrm{Zr}$ in bulk soil for the different genetic horizons remain almost unchanged and are strongly related to the element content of the parent rock, and they attributed that to homogeneity of the soil deposits belonging to the studied pedons [21].

Due to the scarcity of research in this field within most of the Egyptian soil, it was necessary to shed light on and determine the total chemical content of titanium and zirconium elements and soil's mineralogical composition as indicators for investigating soil profile uniformity and development where this kind of researches is an essential stent for agricultural land use planning and management.

\section{Study area}

\section{MATERIALS AND METHODS}

It stretches between longitudes $28^{\circ} 33^{`} 30^{\prime \prime}$ and $28^{\circ} 36^{\prime} 00^{\prime \prime} \mathrm{E}$, and latitudes $30^{\circ} 05^{\prime} 33^{\prime \prime}$ and $30^{\circ} 09^{\prime} 10^{\prime \prime} \mathrm{N}$, occupying approximately $25 \mathrm{~km}^{2}$ of geographical area. It is bordered to the south-east portion of El-Qattara depression, Egyptian western desert and stretches (Fig. 1).

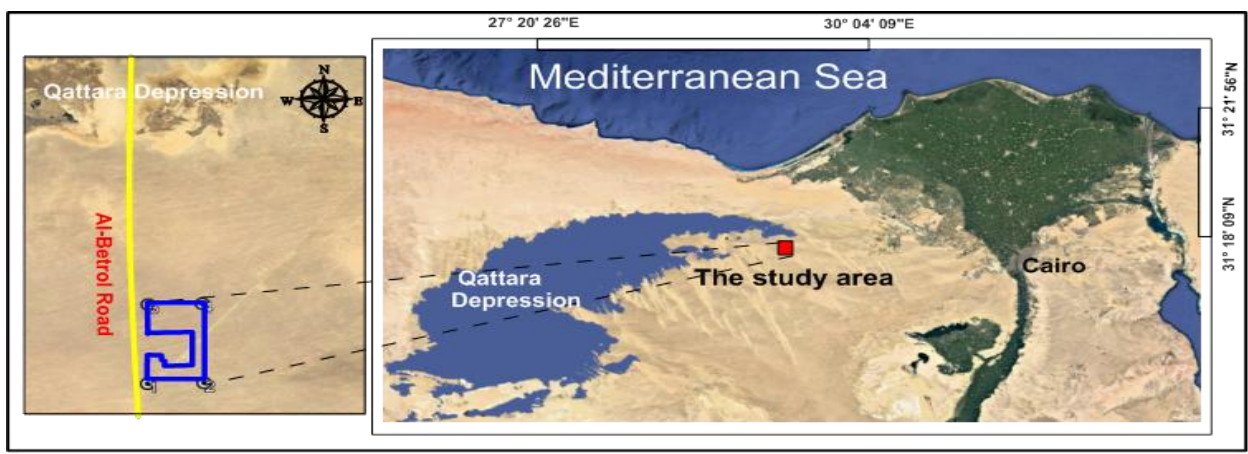

Fig. 1: Location map of the study site

Geologically, the studied portion belonged to Miocene, Pliocene and Quaternary deposits, (Fig. 2). Miocene rocks are represented by Lower Miocene Moghra and Middle Miocene Marmarica Formations, [17]; [3]; [15]; [8]; [23]; [24]. On the basis of geomorphology, the study site is divided into; (1) Gravel plain, and (2) Low land [23], (Fig. 3).

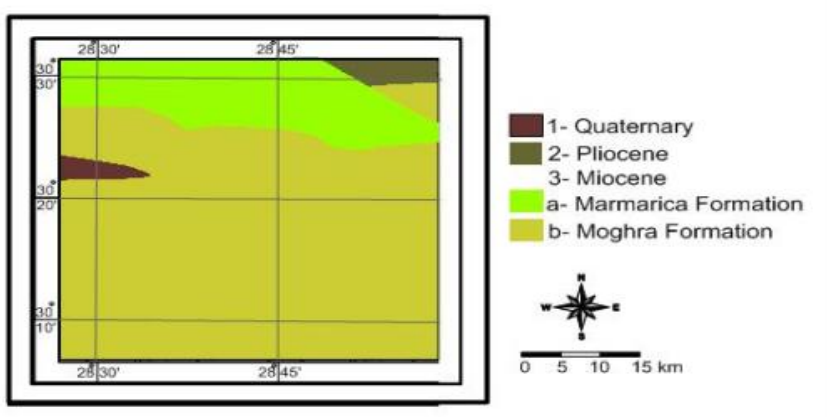

Fig. 2: Geological map of the investigated site, after [3]

\section{Field sampling and laboratory methods}

Five soil profiles were selected on the basis of the recognized geomorphological unites variation and dominant ground elevations, (Fig. 3). Morphological descriptions of these pedons were recorded applying Soil Survey Manual [19]. A total of twenty soil samples were collected from the genetic horizons which were that already identified and described.

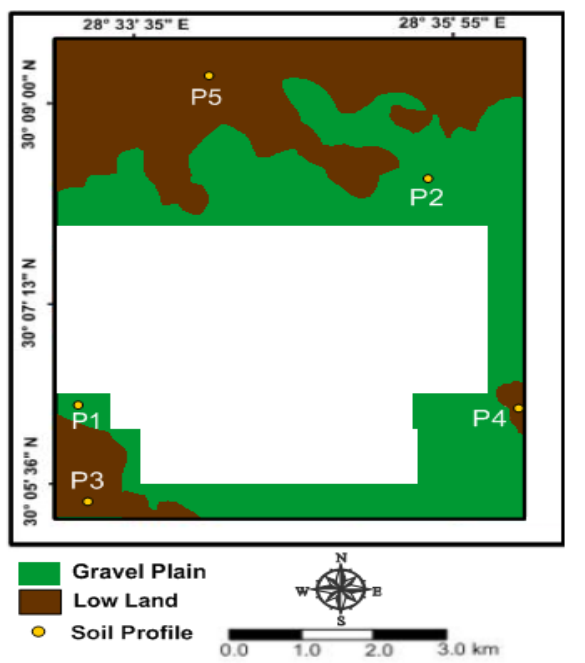

Fig. 3: Geomorphological unites associated with the selected and studied pedons 


\section{Laboratory methods}

Soils samples were oven-dried in the lab and passed through sieve nest to determine gravel content while the $<2$-mm fraction was saved for further analyses: Particle size distribution was determined for coarse-textured samples by dry sieving, [16]. Soil laboratory analyses performed according to [18] including fine soil texture (Pipette method), total calcium carbonates (Volume Calcimeter), electrical conductivity (EC), and soil reaction $(\mathrm{pH})$. Organic matter content was estimated according to [9]. Gypsum was estimated following the method described by [14].

Total chemical titanium (Ti) and zirconium ( $\mathrm{Zr}$ ) contents in the soils was determined after being digested $0.5 \mathrm{~g}$ of soil by a mixture of concentrated $\mathrm{HNO}_{3}(4.0 \mathrm{~mL})+$ concentrated $\mathrm{H}_{2} \mathrm{SO}_{4}(7.0 \mathrm{~mL})+60 \% \mathrm{HClO}_{4}(1.0 \mathrm{~mL})$ as recommended by [9]. $\mathrm{Ti}$ and $\mathrm{Zr}$ were measured by Inductively Coupled Plasma, (ICP).

\section{Mineralogical analyses}

Soil samples were prepared for estimation of heavy and light minerals. Hence, the sand fractions were treated with $0.1 \mathrm{~N} \mathrm{HCl}$ for carbonate removal, $30 \% \mathrm{H}_{2} \mathrm{O}_{2}$ for organic matter and manganese oxides removal and sodium dithionite for free iron oxides removal, [11]. Then they washed with distilled water to ensure the removal of soluble salts, dried and the fraction of $(0.63-0.125 \mathrm{~mm})$ was separated by dry sieving for heavy and light minerals examination. Separation of the minerals was carried out using the bromoform separation technique, after [2]. Minerals were recognized and estimated by stereoscopic microscope model Leica MZ6 and polarizing microscope. The principles applied for identification through optical properties of minerals are those given by [10], [13]. Approximately 500 grains in each slide were examined to minimize the absolute error, [12].

\section{Statistical analysis}

Correlation analyses for Titanium and Zirconium contents along with their minerals percentages were determined using the software of SPSS 16.0 according to [25].

\section{Pedogenesis studies}

\subsection{Soil Morphology}

Soils were deep $(150 \mathrm{~cm}$ depth) and exhibited diversity in soil texture (Table 1). The thickness of the surface horizons varied from 10$50 \mathrm{~cm}$ and assorted with elevations and landscape. Gravels was only distinguished at most of the upper horizons of the studied soil profiles and ranged from 5.5 to $10 \%$. Massive and platy structure were prevalent in the soils of gravel plain while those of low land displayed massive structure at the surface horizons and angular or sub-angular blocky at the deepest ones.

Soil consistence diversified widely from soft to hard in most of the layers to very hard peds occasionally at the deepest horizons. In terms of stickiness and plasticity, soils showed sticky to non-sticky and plastic to no plastic, respectively. However, absence both of soil stickiness and plasticity properties were clearly noticed at upper horizons of the most studied soils.

Soil colour closely reflected the nature of the parent materials exhibited 10YR to $2.5 \mathrm{Y}$ hue, 4 to 8 chroma while the value of the colour matrix did not surpass 7. Gypsum crystals and/or powders were noticed in common to few quantities. Redoximorphic features i.e. iron and/or manganese were found in many medium distinct. The soils displayed slightly effervescent reaction with dilute $\mathrm{HCl}$ without any exception. Boundaries between soil horizons ranged between diffuse to abrupt, referring to apparent differences in the mode of deposition between the genetic horizons of the soils.

\subsection{Soil physical, chemical characteristics and its classification}

Chemical and physical properties were variable and influenced by landscape position, (Table 2). Soil reaction (pH) ranged from 7.10 at 3C4 of (Profile 1) to 8.89 at $\mathrm{C} 1$ of (Profile 4) and decreases irregularly with depth. Electrical conductivity (EC) broadly varied from the lower contents of EC were showed at the surface and subsurface soils, reflecting non-saline to very slightly saline classes. While, a moderately to strongly saline grades were noticed at the deepest horizons.

Organic matter content (OM) tends to be very low and not exceed $1.04 \%$ owing to the location of the soils under hyper-thermic climate conditions and not exploited it for agriculture along with scarce of natural vegetation cover. Calcium carbonate $\left(\mathrm{CaCO}_{3}\right)$ contents ranged amidst $(0.80-2.40 \%)$, which is interpreting why it displayed slight effervescent with $\mathrm{HCl}$ at the field. Gypsum formations were distinctly noticed at the subsurface horizons, where its determined values ranged between traces to $8.90 \%$.

Total sand content showed the lowest value $(42.80 \%$ ) at 2C4 horizon of Profile 4 (low land), while it reached up to $100 \%$ at most of the other surface and subsurface layers of the studied soils. As well, a significant difference in silt contents is observed, where it varied between (8-22\%), while clay percentages do not override $39.20 \%$. Hence, texture of the inspected soils ranged broadly amidst coarse sand and clay loam where the sacrificial coarse texture was associated with slight gravel content.

Based on morphological features, along with their analytical data, soils were classified according to USDA System of soil classification [22] as Typic Torripsamments, (Table 2). These feedbacks referred to non maturity of the investigated soils where it matched with the obtained result by [5]

\subsection{Total titanium $(\mathrm{Ti})$ and zirconium $(\mathrm{Zr})$ and their distribution in soil}

Data in table 3 showed that total (Ti) ranged between 139.42 and $1736.8 \mathrm{mg} \mathrm{kg}^{-1}$. Where the lowest value was found at soils of gravel plain; 2C4 horizon of profile 2 while the highest was settled at sacrificial soils of low land; profile 4 .

Total $(\mathrm{Zr})$ varied between 13.22 and $112.86 \mathrm{mgKg}^{-1}$ where the deepest soils of gravel plain; profile 2 included on the minimum content of $\mathrm{Zr}$, while the maximum one was presented in $2 \mathrm{C} 4$ layer of profile 3 within low land soils. Noteworthy, that those chemical contents of total $\mathrm{Ti}$ and $\mathrm{Zr}$ showed irregular distribution with depth within the studied soils which are indicating non-uniformity of their parent materials.

\subsection{Mineralogy of the sand fraction \\ 1.4.1.Light minerals} samples.

Frequency distribution of light minerals represented in table 4 refers to the sovereignty of quartz followed by feldspars in the studied 
Table1: Some morphological soil properties of the south-east portion of El-Qattara depression

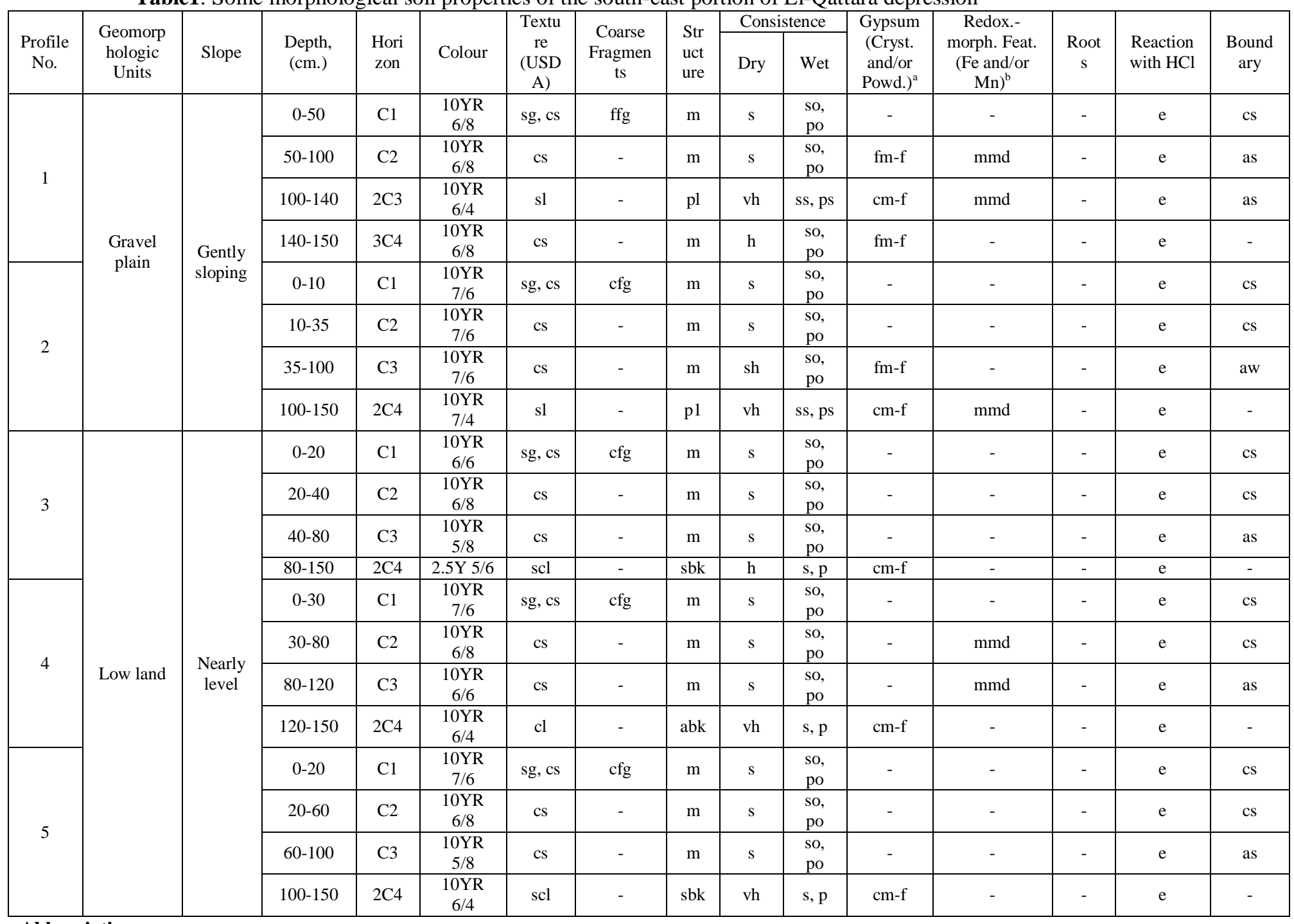

\section{Abbreviations:}

Texture (USDA):

Coarse Fragments:

Structure:

Consistency:

a

b. sg, cs-slightly gravelly coarse sand; cs-coarse sand; sl-sandy loam; scl-sandy clay loam; cl-clay loam

ffg-few fine gravel; cfg-common fine gravel

m-massive; pl-platy; sbk-subangular blocky; abk-angular blocky (Dry): s-soft; vh-very hard; h-hard; sh-slightly hard, (Wet): so-non sticky; ss-slightly sticky; s-sticky; po-non plastic; ps-slightly plastic; p-plastic

fm-f: few medium and fine; $\mathrm{cm}-\mathrm{f}$ : common medium and fine mmd-many medium distinct
Reaction with HCl: e-slightly effervescent

Boundary: cs-clear smooth; asabrupt smooth; aw-abrupt wavy

Table 2: Some soil chemical and physical properties of the south-east portion of El-Qattara depression

\begin{tabular}{|c|c|c|c|c|c|c|c|c|c|c|c|c|c|c|c|c|c|c|c|}
\hline \multirow{2}{*}{ 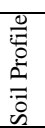 } & \multirow{2}{*}{ 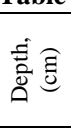 } & \multirow{2}{*}{ 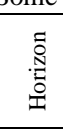 } & \multirow[b]{2}{*}{ 壱 } & \multirow{2}{*}{$\begin{array}{c}{ }^{\top} \bar{g} \\
\underline{y} \\
y\end{array}$} & \multicolumn{4}{|c|}{$\%$} & \multicolumn{6}{|c|}{ Dry sieving $(\%)^{1}$} & \multicolumn{4}{|c|}{$\begin{array}{l}\text { Particle size distribution } \\
(\mathrm{g} / 100 \mathrm{~g})\end{array}$} & \multirow[b]{2}{*}{$\begin{array}{c}\text { Texture } \\
\text { class }^{2}\end{array}$} \\
\hline & & & & & ¿ & ש̃ & 总亦 & हैं & 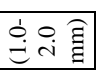 & 它 & 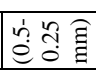 & , $\frac{1}{0}$ in & \multicolumn{2}{|c|}{ 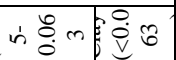 } & 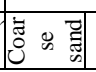 & 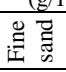 & 击 & 肎 & \\
\hline \multirow{5}{*}{1} & \multicolumn{18}{|c|}{ Gravel Plain, Gently Sloping, Typic Torripsamments } & \\
\hline & $0-50$ & $\mathrm{C} 1$ & 8.80 & 0.8 & 0.17 & 2.0 & \begin{tabular}{ll|}
0.0 \\
\end{tabular} & 5.50 & 21.53 & 65.45 & 20 & 8.57 & 3.12 & 1.13 & - & - & 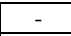 & - & $\mathrm{sg}, \mathrm{cs}$ \\
\hline & $\begin{array}{l}50- \\
100\end{array}$ & $\mathrm{C} 2$ & 7.93 & 2.0 & 0.44 & 1.6 & 1.7 & - & 14.49 & 78.24 & 0.15 & 4.62 & 1.78 & 0.72 & - & - & - & - & cs \\
\hline & $\begin{array}{l}100- \\
140 \\
\end{array}$ & $2 \mathrm{C} 3$ & 7.60 & 16.0 & 0.24 & 0.8 & 4.8 & - & - & - & - & - & - & - & 42.3 & 18.5 & 22.0 & 17.2 & sl \\
\hline & $\begin{array}{l}140- \\
150\end{array}$ & $3 \mathrm{C} 4$ & 7.10 & 9.0 & 0.14 & 1.2 & 1.8 & - & 26.52 & 56.45 & 3.96 & 7.46 & 3.17 & 2.44 & - & - & - & - & cs \\
\hline \multirow[t]{2}{*}{2} & $0-10$ & $\mathrm{C} 1$ & 8.10 & 3.0 & 0.19 & 1.6 & 0.0 & 10.0 & 11.22 & 53.96 & 4.09 & 19.72 & 9.8 & 1.21 & - & - & - & - & sg, cs \\
\hline & $10-35$ & & 7.90 & & 0.17 & 6 & .0 & & 49 & 62.2 & & 8.95 & & & & & & & \\
\hline
\end{tabular}




\begin{tabular}{|c|c|c|c|c|c|c|c|c|c|c|c|c|c|c|c|c|c|c|c|}
\hline & $\begin{array}{l}35- \\
100\end{array}$ & $\mathrm{C} 3$ & 7.95 & 4.2 & 0.17 & 2.0 & 1.7 & - & 21.48 & 59.83 & 3.87 & 8.86 & 4.4 & 1.56 & - & - & - & - & cs \\
\hline & $\begin{array}{l}100- \\
150\end{array}$ & $2 \mathrm{C} 4$ & 7.70 & 6.4 & 0.07 & 1.6 & 4.4 & - & - & - & - & - & - & - & 32.1 & 44.7 & 8.0 & 15.2 & sl \\
\hline \multicolumn{20}{|c|}{ Low Land, Nearly Level, Typic Torripsamments } \\
\hline \multirow{4}{*}{3} & $0-20$ & $\mathrm{C} 1$ & 8.60 & 1.2 & 0.04 & 2.4 & 0.0 & 8.50 & 9.97 & 49.27 & 4.31 & 17.14 & 10.26 & 9.05 & - & - & - & - & $\mathrm{sg}, \mathrm{cs}$ \\
\hline & $20-40$ & $\mathrm{C} 2$ & 8.80 & 1.3 & 0.17 & 0.8 & 0.0 & - & 19.16 & 55.39 & 2.92 & 6.87 & 10.37 & 5.29 & - & - & - & - & cs \\
\hline & $40-80$ & C3 & 8.50 & 1.0 & 1.02 & 1.2 & 0.0 & - & 25.81 & 59.97 & 1.95 & 3.73 & 4.06 & 4.4 & - & - & - & - & cs \\
\hline & $\begin{array}{l}80- \\
150\end{array}$ & $2 \mathrm{C} 4$ & 7.50 & 9.9 & 0.44 & 1.5 & 6.3 & - & - & - & - & - & - & - & 35.9 & 18.9 & 20.0 & 25.2 & $\mathrm{scl}$ \\
\hline \multirow{4}{*}{4} & $0-30$ & $\mathrm{C} 1$ & 8.89 & 0.7 & 0.24 & 1.6 & 0.0 & 9.50 & 13.77 & 63.19 & 3.16 & 10.99 & 6.73 & 2.16 & - & - & - & - & $\mathrm{sg}, \mathrm{cs}$ \\
\hline & $30-80$ & $\mathrm{C} 2$ & 7.85 & 3.0 & 0.17 & 1.2 & 0.0 & - & 16.00 & 65.43 & 3.99 & 8.50 & 4.74 & 1.34 & - & - & - & - & cs \\
\hline & $\begin{array}{l}80- \\
120 \\
\end{array}$ & $\mathrm{C} 3$ & 7.95 & 4.5 & 1.02 & 1.7 & 0.0 & - & 12.51 & 60.70 & 6.70 & 13.06 & 5.56 & 1.47 & - & - & - & - & cs \\
\hline & $\begin{array}{l}120- \\
150 \\
\end{array}$ & $2 \mathrm{C} 4$ & 7.40 & 13.0 & 0.48 & 1.6 & 8.9 & - & - & - & - & - & - & - & 20.7 & 22.1 & 18.0 & 39.2 & $\mathrm{cl}$ \\
\hline \multirow{4}{*}{5} & $0-20$ & $\mathrm{C} 1$ & 8.82 & 1.0 & 0.14 & 2.0 & 0.0 & 8.00 & 11.87 & 56.23 & 3.73 & 14.06 & 8.49 & 5.62 & - & - & - & - & sg, cs \\
\hline & $20-60$ & $\mathrm{C} 2$ & 8.50 & 2.0 & 0.18 & 1.0 & 0.0 & - & 17.58 & 60.41 & 3.45 & 7.68 & 7.55 & 3.33 & - & - & - & - & cs \\
\hline & $\begin{array}{l}60- \\
100\end{array}$ & $\mathrm{C} 3$ & 8.40 & 3.1 & 1.04 & 1.5 & 0.0 & - & 19.16 & 60.33 & 4.32 & 8.39 & 4.81 & 2.99 & - & - & - & - & $\mathrm{cs}$ \\
\hline & $\begin{array}{l}100- \\
150\end{array}$ & $2 \mathrm{C} 4$ & 7.50 & 11.5 & 0.46 & 1.6 & 7.6 & - & - & - & - & - & - & - & 30.3 & 18.5 & 19.0 & 32.2 & $\mathrm{scl}$ \\
\hline
\end{tabular}

Table 3: Total titanium (Ti) and zirconium ( $\mathrm{Zr}$ ) in soils of the south-east portion of El-Qattara depression

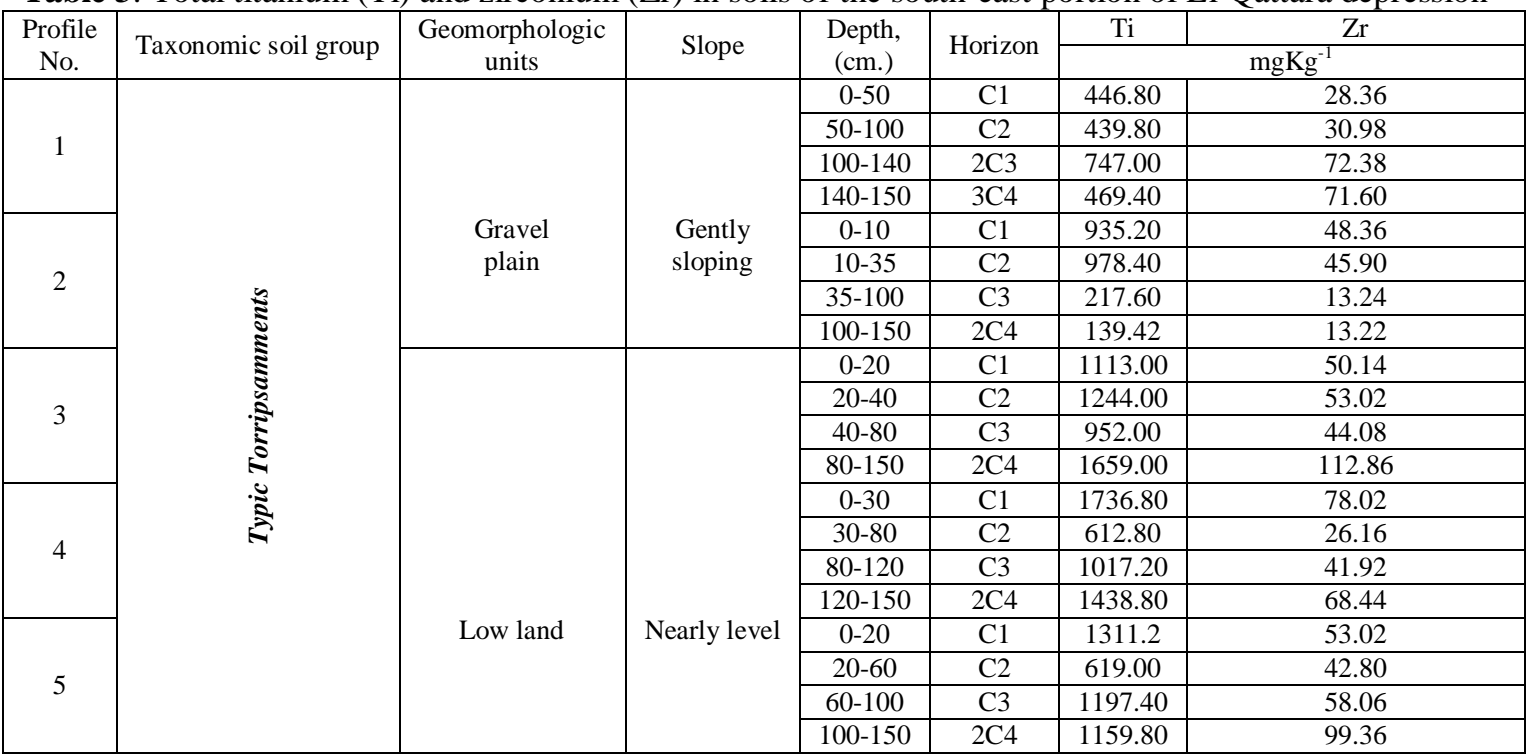

Quartz frequency ranged between (18.4\% at subsurface soils of low land; profile 5) and (81.8\% at C2 of profile 1; soils of gravel plain) of the light fraction. Feldspars occur in three components are orthoclase, plagioclase, and microcline arranged in descending order in terms of quantity. Total feldspars constitute about 18.2 to $81.6 \%$ of the light fraction. Its minimal magnitude was observed at soils of gravel plain; profile $1(50-100 \mathrm{~cm})$ while the maximum one was noticed at the deepest layer of profile 5; low land soils. Both quartz and feldspars contents exhibited unequal apportionment with depth within the investigated soils. Index figure varies between 2.7 to 10.1 with no specific pattern vertically. Data reflected that ratios of the index figure are quite different from one layer to another, indicating a multi- depositional regime.

\subsubsection{Heavy minerals}

Data in (Table 5) showed that heavy minerals were presented in two groups; opaques and non-opaques. Opaque contents ranged between 13.3 and $50.0 \%$, while total non-opaques ranged between 50.0 and $86.7 \%$. Their higher and lower contents occupied subsurface soils of the gravel plain (profile1). Pyroboles which are non-opaques included mainly on the pyroxenes and amphiboles. Pyroxenes constituted 21.1 to $40.0 \%$, while amphiboles were mainly formed of hornblende ranged between 20.2 to $42.8 \%$ of the total non-opaques. The highest percentages of pyroxenes were found at subsurface soils of gravel plain; profile1 and subsurface layer ( $30-80 \mathrm{~cm}$.) of profile 4 ; soils of the low land, while the maximum ones for amphiboles were only noticed at C1 layer of profile 3 in soils of the low land. Pyroboles frequency showed unequal allocation with depth. Parametamorphic minerals are represented as Epidote and Garnet, and classified as stable to slightly stable. Epidote content does not overrun $10.8 \%$ of the total non-opaques. Frequency distribution of garnet showed him as the dominant member within the total parametamorphic minerals, where its percentages lay between $4.2 \%$ and $18.4 \%$ of the non-opaque minerals. The cephalic allocation of these minerals does not display any particular trend with depth 
N.M.A. Bahnasawy et al., 2019. Mineralo-chemical study of Titanium and Zirconium as indicators for soil profile uniformity and development. American-Eurasian Journal of Sustainable Agriculture. 13(3): 10-20. DOI: 10.22587/aejsa.2019.13.3.2

Table 4: Frequency distribution of the light minerals $(0.125-0.063 \mathrm{~mm})$ in the sand fraction of the south-east portion of El-Qattara depression

\begin{tabular}{|c|c|c|c|c|c|c|c|c|c|c|c|c|c|}
\hline \multirow{3}{*}{$\begin{array}{c}\text { Profile } \\
\text { No. }\end{array}$} & \multirow{3}{*}{ 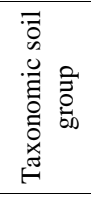 } & \multirow{3}{*}{ 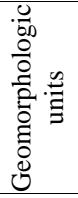 } & \multirow{3}{*}{$\frac{\ddot{2}}{\sqrt{2}}$} & \multirow{3}{*}{$\begin{array}{l}\text { Depth, } \\
\text { (cm.) }\end{array}$} & \multirow[b]{3}{*}{$\begin{array}{l}\text { Hori } \\
\text { zon }\end{array}$} & \multirow{2}{*}{$\begin{array}{c}\text { Weight } \\
\text { of } \\
\text { light }\end{array}$} & \multirow{3}{*}{$\begin{array}{c}\text { Weight of } \\
\text { heavy }\end{array}$} & \multirow[b]{3}{*}{$\begin{array}{c}\text { Quartz } \\
\%\end{array}$} & \multicolumn{3}{|c|}{ Feldspars \% } & \multirow{3}{*}{$\begin{array}{c}\text { Total } \\
\text { feldspars } \\
\%\end{array}$} & \multirow{3}{*}{$\begin{array}{c}\text { Index } \\
\text { figure } \\
\%\end{array}$} \\
\hline & & & & & & & & & \multirow{2}{*}{$\begin{array}{l}0 \\
\text { o } \\
\frac{\tilde{J}}{0} \\
0 \\
\stackrel{0}{0} \\
0\end{array}$} & \multirow{2}{*}{$\begin{array}{l}0 \\
0 \\
\frac{\pi}{0} \\
.0 \\
\frac{\pi}{20} \\
\frac{\pi}{2}\end{array}$} & \multirow{2}{*}{ 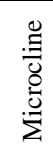 } & & \\
\hline & & & & & & & & & & & & & \\
\hline \multirow{4}{*}{1} & \multirow{20}{*}{$\stackrel{.}{\stackrel{\Xi}{*}}$} & \multirow{8}{*}{$\begin{array}{l}\Xi \\
\frac{\pi}{2} \\
\bar{D} \\
\stackrel{\pi}{0} \\
0\end{array}$} & \multirow{8}{*}{ 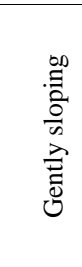 } & $0-50$ & $\mathrm{C} 1$ & 11.9 & 1.0 & 79.7 & 10.1 & 5.1 & 5.1 & 20.3 & 8.4 \\
\hline & & & & $50-100$ & $\mathrm{C} 2$ & 4.6 & 0.3 & 81.8 & 8.1 & 3.0 & 7.1 & 18.2 & 6.5 \\
\hline & & & & $100-140$ & $2 \mathrm{C} 3$ & 9.6 & 0.6 & 27.0 & 49.0 & 20.0 & 4.0 & 73.0 & 6.3 \\
\hline & & & & $140-150$ & $3 \mathrm{C} 4$ & 11.9 & 0.4 & 78.1 & 9.1 & 5.1 & 7.7 & 21.9 & 3.4 \\
\hline \multirow{4}{*}{2} & & & & $0-10$ & $\mathrm{C} 1$ & 22.9 & 0.9 & 81.6 & 5.1 & 8.1 & 5.2 & 18.4 & 3.9 \\
\hline & & & & $10-35$ & $\mathrm{C} 2$ & 6.9 & 0.4 & 76.1 & 12.0 & 5.1 & 6.8 & 23.9 & 5.8 \\
\hline & & & & $35-100$ & $\mathrm{C} 3$ & 9.1 & 0.4 & 56.6 & 30.0 & 10.0 & 3.4 & 43.4 & 4.4 \\
\hline & & & & $100-150$ & $2 \mathrm{C} 4$ & 18.0 & 0.6 & 71.8 & 15.2 & 10.1 & 2.9 & 28.2 & 3.3 \\
\hline \multirow{4}{*}{3} & & \multirow{12}{*}{$\begin{array}{l}\overrightarrow{0} \\
\frac{\vec{E}}{3} \\
3 \\
0 \\
1\end{array}$} & \multirow{12}{*}{ 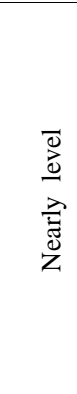 } & $0-20$ & $\mathrm{C} 1$ & 18.1 & 0.9 & 69.6 & 20.2 & 5.1 & 5.1 & 30.4 & 5.0 \\
\hline & & & & $20-40$ & $\mathrm{C} 2$ & 6.9 & 0.4 & 60.2 & 25.5 & 8.2 & 6.1 & 39.8 & 5.8 \\
\hline & & & & $40-80$ & $\mathrm{C} 3$ & 5.1 & 0.3 & 66.3 & 25.5 & 3.1 & 5.1 & 33.7 & 5.9 \\
\hline & & & & $80-150$ & $2 \mathrm{C} 4$ & 7.4 & 0.2 & 50.5 & 33.3 & 10.1 & 6.1 & 49.5 & 2.7 \\
\hline \multirow{4}{*}{4} & & & & $0-30$ & $\mathrm{C} 1$ & 16.6 & 0.4 & 62.6 & 20.2 & 10.1 & 7.1 & 37.4 & 2.4 \\
\hline & & & & $30-80$ & $\mathrm{C} 2$ & 13.9 & 0.5 & 53.4 & 30.3 & 8.1 & 8.2 & 46.6 & 3.6 \\
\hline & & & & $80-120$ & $\mathrm{C} 3$ & 14.6 & 0.5 & 62.3 & 25.5 & 7.1 & 5.1 & 37.7 & 3.4 \\
\hline & & & & $120-150$ & $2 \mathrm{C} 4$ & 8.2 & 0.4 & 55.8 & 35.7 & 4.1 & 4.4 & 44.2 & 4.9 \\
\hline \multirow{4}{*}{5} & & & & $0-20$ & $\mathrm{C} 1$ & 14.7 & 0.7 & 50.5 & 30.3 & 12.1 & 7.1 & 49.5 & 4.8 \\
\hline & & & & $20-60$ & $\mathrm{C} 2$ & 6.9 & 0.7 & 57.7 & 25.8 & 10.3 & 6.2 & 42.3 & 10.1 \\
\hline & & & & $60-100$ & $\mathrm{C} 3$ & 5.1 & 0.5 & 53.6 & 30.9 & 7.2 & 8.3 & 46.4 & 9.8 \\
\hline & & & & $100-150$ & $2 \mathrm{C} 4$ & 9.9 & 0.3 & 18.4 & 45.5 & 30.0 & 6.1 & 81.6 & 3.0 \\
\hline
\end{tabular}

Resistant minerals consisted of zircon, rutile and tourmaline. Zircon frequently observed in incommodious amounts within the examined samples (1.4 to $5.9 \%$ ) where it showed regular rising with depth only at (profile 3; low land soils) while was not presented by the same trend at the rest of soil profiles. Rutile is largely found in all horizons of the studied profiles with assorted quantities (1.6-12.0\%) detected higher contents at most of the subsurface soils. Tourmaline is commonly distinguished in minor amounts within most of the examined samples (1.1 to $1.88 \%)$. Its greatest frequency occurred at surface soils of profile 5; low land. Monazite showed that their frequency distribution within the non-opaque minerals ranged between 0.2 and $10.0 \%$. The highest percentage is recorded in the deepest layer of profile 3, while the lowest is found in the deepest layer of profile 1 . Titanite is identified in all the investigated samples with amounts ranging from 1.7 to $12.1 \%$ of the non-opaque minerals. The highest content characterized $2 \mathrm{C} 4$ layer of profile 3 , while the minimum was noticed in $\mathrm{C} 2$ and $3 \mathrm{C} 4$ layers of profile 1 . Biotite frequency varied from 1.3 to $10.0 \%$ of the non-opaque minerals, and the highest percentage is abundant in soils of low land. It was noticed that Monazite, Titanite, and Biotite minerals presented irregular vertical distribution with depth within all the assessed soil profiles. Statistical analyses showed that the correlation coefficient (r) between Titanium element (Ti) with Rutile, and Titanite minerals was $(0.316)$, (0.151), receptivity while the coefficient presented a value of $(-0.107)$ between both of Zirconium element ( $\mathrm{Zr}$ ) and Zircon mineral. This is referring to weak correlation relationship and this, in turn, indicating on stability degree of the minerals which bearing Titanium and Zirconium to release both of them even after more than thousands of years on formation of the studied soils which are stilled young, Fig. (4).
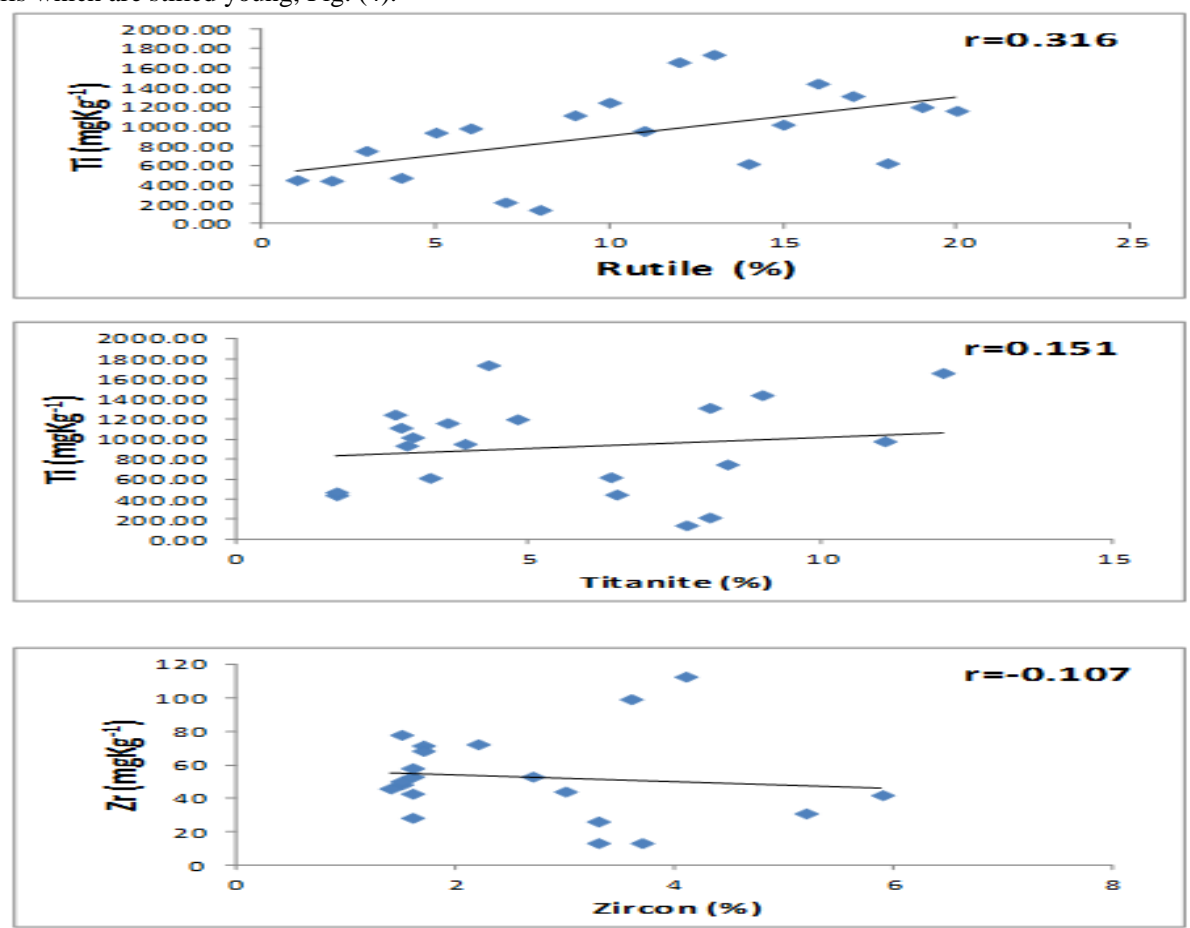

Fig. 4: correlation coefficient between Titanium element (Ti) with Rutile, and Titanite minerals, and Zirconium element (Zr) with Zircon mineral. 


\subsection{Soil development and its maturity assessment}

Outcomes in (table 5 and figure 5) clarified that the less stable minerals (Pyroboles) exist in high percentages at the inspected pedons, while resistant minerals such as zircon $(Z)$, rutile $(\mathrm{R})$, and tourmaline $(\mathrm{T})$ have occurred in lower amounts. Moreover, stable minerals which are called by "ZTR index" and used for maturity assessment reflected values less than $75 \%$ within the study area.

This is indicating that the investigated soils are less impacted by weathering, recently formed, immature, weakly developed, and has the low influence of pedogenic processes. These outputs corresponded with the obtained data of soil classification.

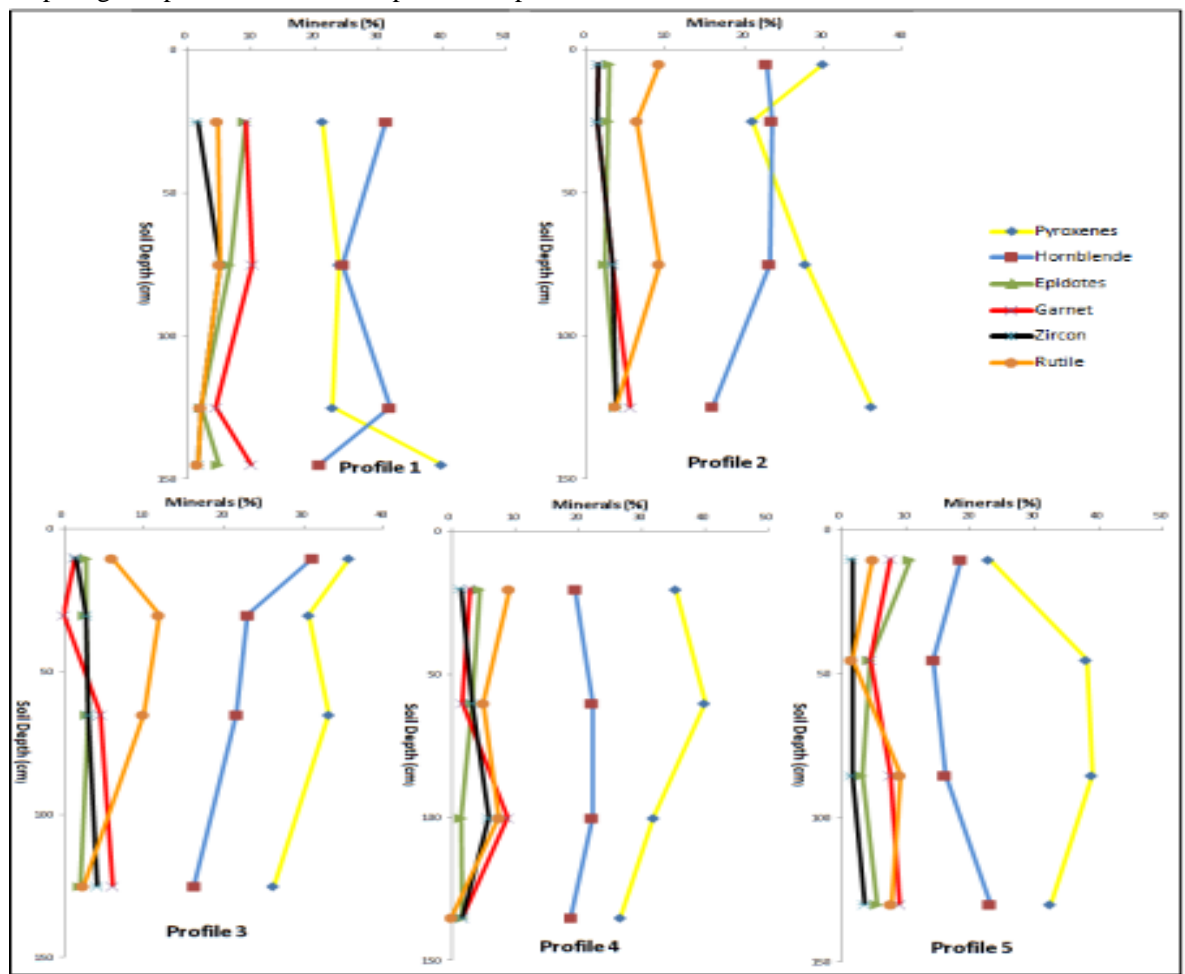

Fig. 5: Depth-wise distribution of (zircon \& rutile) along with pyroboles as indicators for soil profile development and parent materials uniformity

Microscopic investigations (Plate 1) pointed out that most of grains are angular to subangular with occurrence of some subrounded grains that means nearby the source of sediments. On the other hand, presence of subrounded pitted and polished grains indicates that deposits of the study area are re-transported. This is indicating that sediments which constitute the studied soils are mostly transported by water from near source.

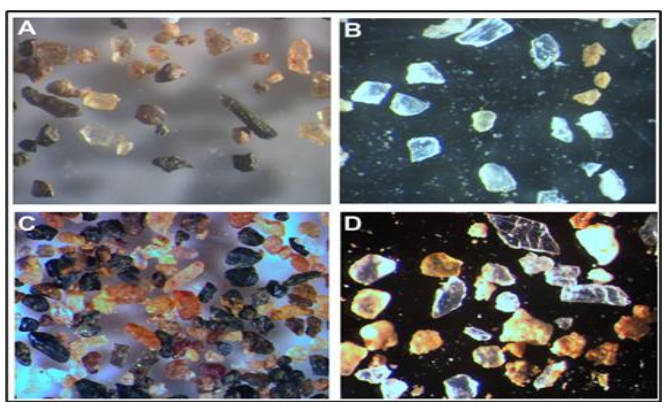

Plate 1: Microscopic graphs of the dominant minerals in the sand fraction $(0.125-0.063 \mathrm{~mm})$ within the studied soils of gravel plain (A\&B) and low land (C\&D)

\subsection{Soil profile uniformity appraisement}

Heavy minerals represent criteria for scrutinizing genesis and uniformity of soil parent material. Many authors like, [1]; [6]; [4] and others used the ratio between Zircon/Tourmaline (Z/T), Zircon/Rutile (Z/R), and Zircon/Rutile + Tourmaline (Z/R+T) to demonstrate homogeneity or discontinuity of parent material. So, stratifying ratios of $Z / R, Z / T, Z / R+T$, index figure, along with weathering ratios were used as a criterion for assessment uniformity of parent material of the studied soils to reinforce chemical data of both zirconium and titanium which are used for same purpose of study.

The mineralogical ratios are given in (table 6) and indicated that profiles of south-east portion of El-Qattara depression related to soils of gravel plain and low land; Typic Torripsamments showed conspicuous differences in the uniformity ratios, index figure, and weathering ratios throughout the successive layers. This is indicating that the parent material is not uniform along with the whole profile and mostly derived from more than one origin or formed due to multi-depositional regimes.

These feedbacks have to put in consideration of the land use planner for agriculture in order to determine the most suitable soil management for sustaining those kinds of land resources. 
N.M.A. Bahnasawy et al., 2019. Mineralo-chemical study of Titanium and Zirconium as indicators for soil profile uniformity and development. American-Eurasian Journal of Sustainable Agriculture. 13(3): 10-20. DOI: 10.22587/aejsa.2019.13.3.2

Table 6: Ratios of resistant minerals and index figure, along with weathering ratios in the separated sand at the south-east portion of ElQattara depression

\begin{tabular}{|c|c|c|c|c|c|c|c|c|c|}
\hline \multirow{2}{*}{ Profile No. } & \multirow{2}{*}{$\begin{array}{l}\text { Depth, } \\
\text { (cm.) }\end{array}$} & \multirow{2}{*}{ Horizon } & \multicolumn{3}{|c|}{ Stable minerals } & \multirow{2}{*}{$\begin{array}{l}\text { Index } \\
\text { figure }\end{array}$} & \multicolumn{3}{|c|}{ Weathering ratios ${ }^{a}$} \\
\hline & & & $\mathrm{Z} / \mathrm{R}$ & $\mathrm{Z} / \mathrm{T}$ & $\mathrm{Z} / \mathrm{R}+\mathrm{T}$ & & Wr1 & $\mathrm{Wr} 2$ & Wr3 \\
\hline \multicolumn{10}{|c|}{ Gravel Plain, Gently Sloping, Typic Torripsamments } \\
\hline \multirow{4}{*}{1} & $0-50$ & $\mathrm{C} 1$ & 0.33 & 1.46 & 0.27 & 8.4 & 22.33 & 11.56 & 1.19 \\
\hline & $50-100$ & $\mathrm{C} 2$ & 1.00 & 4.00 & 0.80 & 6.5 & 9.19 & 3.75 & 0.80 \\
\hline & $100-140$ & $2 \mathrm{C} 3$ & 1.01 & 1.57 & 0.61 & 6.3 & 17.00 & 8.83 & 1.72 \\
\hline & $140-150$ & $3 \mathrm{C} 4$ & 1.00 & 1.00 & 0.50 & 3.4 & 21.60 & 6.10 & 0.97 \\
\hline \multirow{4}{*}{2} & $0-10$ & $\mathrm{C} 1$ & 0.16 & 1.00 & 0.14 & 3.9 & 23.93 & 7.35 & 0.50 \\
\hline & $10-35$ & $\mathrm{C} 2$ & 0.22 & 0.82 & 0.17 & 5.8 & 15.87 & 7.61 & 3.13 \\
\hline & $35-100$ & C3 & 0.36 & 1.94 & 0.30 & 4.4 & 10.82 & 4.66 & 1.36 \\
\hline & $100-150$ & $2 \mathrm{C} 4$ & 1.00 & 2.64 & 0.73 & 3.3 & 11.75 & 3.14 & 1.16 \\
\hline \multicolumn{10}{|c|}{ Low Land, Nearly Level, Typic Torripsamments } \\
\hline \multirow{4}{*}{3} & $0-20$ & $\mathrm{C} 1$ & 0.25 & 0.94 & 0.20 & 5.0 & 25.35 & 10.10 & 0.90 \\
\hline & $20-40$ & $\mathrm{C} 2$ & 0.23 & 2.10 & 0.20 & 5.8 & 17.0 & 5.75 & 0.33 \\
\hline & $40-80$ & $\mathrm{C} 3$ & 0.30 & 2.00 & 0.25 & 5.9 & 14.10 & 4.80 & 0.67 \\
\hline & $80-150$ & $2 \mathrm{C} 4$ & 1.64 & 3.42 & 1.11 & 2.7 & 8.77 & 3.10 & 1.89 \\
\hline \multirow{4}{*}{4} & $0-30$ & $\mathrm{C} 1$ & 0.17 & 1.00 & 0.14 & 2.4 & 22.10 & 6.50 & 0.97 \\
\hline & $30-80$ & $\mathrm{C} 2$ & 0.66 & 2.36 & 0.52 & 3.6 & 16.32 & 4.72 & 0.36 \\
\hline & $80-120$ & C3 & 0.79 & 3.93 & 0.66 & 3.4 & 8.99 & 3.00 & 0.39 \\
\hline & $120-150$ & $2 \mathrm{C} 4$ & 0.17 & 1.00 & 0.15 & 4.9 & 18.15 & 5.53 & 1.18 \\
\hline \multirow{4}{*}{5} & $0-20$ & $\mathrm{C} 1$ & 0.33 & 0.84 & 0.24 & 4.8 & 14.46 & 5.31 & 1.37 \\
\hline & $20-60$ & $\mathrm{C} 2$ & 1.00 & 0.89 & 0.47 & 10.1 & 17.88 & 4.21 & 1.90 \\
\hline & $60-100$ & C3 & 0.17 & 0.94 & 0.15 & 9.8 & 20.79 & 4.91 & 0.48 \\
\hline & $100-150$ & $2 \mathrm{C} 4$ & 0.46 & 2.25 & 0.38 & 3.0 & 12.15 & 4.46 & 0.35 \\
\hline
\end{tabular}

${ }^{\mathrm{a}}: \mathrm{Wr} 1=$ Pyroxenes + Amphiboles/Zircon +Tourmaline, Wr2 = Hornblende/Zircon + Tourmaline and Wr3 = Biotite/Zircon+ Tourmaline

\section{CONCLUSION}

The current research has extended some insight into the relative merits in the use of heavy minerals and their ratios along with (Ti) and ( $\mathrm{Zi})$ contents in studying the uniformity of soil parent materials and assessment development. Soils of the studied portion are weakly developed, young, and influenced by geo-genic processes rather than pedogenic. Therefore, soil parent material was the major factor between the other forming variables in the determination of the pedogenesis setting of the study area. Moreover, the investigation illustrated that soil parent materials of the research area are heterogeneous and formed of multi-depositional regimes as indicated by uniformity ratios, index figures, weathering ratios of the identified minerals along with $(\mathrm{Zr})$ and $(\mathrm{Ti})$ contents. These results should be put in the account within land-use planning for agricultural purposes so that sustaining these kinds of land resources for longer time of productivity.

Acknowledgements

This work was funded by the Desert Research Center (DRC), Egypt. Research No. 6.

\section{REFERENCES}

[1] Bahnasawy, N.MA., 2006. Sand Mineralogy as a Criterion for Soil Uniformity North West Wadi El-Natrun., Egyptian J. Soil Sci.., Article 11, 56(4): 739-759.

[2] Biswas, T. D. and S. K. Mukherjee, 2017. Text Book of Soil Science. McGraw-Hill Inc., US; 2nd edition.

[3] CONOCO, 1987. Geologic Map of Egypt. Egyptian General Authority for Petroleum (UNESCO Joint Map Project), 20 Sheets, Scale 1:500 000, Cairo.

[4] El Kady, M.M. and T.M.H.Yossif, 2017. Genesis and Parent Material Uniformity Appraisal of some Adjacent Soils to Bani Mazar-El Boiety Road, El Minia, Egypt. Alexandria Science Exchange Journal, 38(3): 397-411.

[5] El Kady, M.M. and E.F. Essa, 2018. Classification and land capability of some soils at El-Moghra Depression, Egypt. Egyptian J. Desert Res., 68(2): 243-258.

[6] EL Kady, M.M., 2008. Soils Distribution and Development of El Alamein - Wadi El Natrun Area, Egypt. M.Sc. Thesis, Fac. Agric., Al-Azhar University, Cairo, Egypt.

[7] Fitzpatrick, R.W. and D.J. Chittleborough, 2002. Titanium and Zirconium Minerals. In Soil Mineralogy with Environmental Applications, Eds., Dixon, J.B. and D.G. Schulze. SSSA, Madison, WI, pp: 667-690.

[8] Hassan, S.M., R.J. Steel, A. El Barkooky, M. Hamdan, C. Olariu, and M.A. Helper, 2012. Stacked, lower Miocene tidedominated estuary deposits in a transgressive succession, Western Desert, Egypt. Sediment. Geol. 282: 241-255.

[9] Jackson, M.L. 2005. Soil Chemical Analysis: Advanced Course. UWMadison Libraries Parallel Press, USA, 930 p.

[10] Jay, A.S. 2015. Forensic chemistry: fundamental and applications. Foren. Sc., Mi., ISBN: 978-1-118-89772-0, WileyBlackwell, $542 \mathrm{p}$.

[11] Kettler, T.A., J.W. Doran, and T.L. Gilbert, 2001. Soil particle size: simplified method for soil particle-size determination to accompany soil-quality analysis, S. Sci. Soc. Amer. J., 65: 849-852.

[12] Mahaney, W.C. 2002. Atlas of Sand Grain Surface Textures and Applications, Oxford University Press, Science, 237 p. [13] Mallik, T.K. 2018. A guide to rapid identification of heavy minerals and highlights of heavy mineral distribution pattern along Indian coasts. MOJ Eco Environ Sci. 3(4): 260-263.

[14] Omran, E.S.E. 2016. A simple model for rapid gypsum determination in arid soils. Model. Earth Syst. Environ., (2)185: $1-12$.

[15] Pickford, M., E.R. Miller, A.N. El-Barkooky, 2009. Suidae and Sanitheriidae from Wadi Moghra, Early Miocene, Egypt. Acta Palaeontol. Pol. 55: 1-11.

[16] Retsch, G.H. 2009. Sieve analysis taking a close look quality. P. 1:52. In. S.B.N. 10, 0-8493-7038-8. 
[17] Said, R. 1962. The geology of Egypt. Elsevier Publishing Company, Amsterdam, p 377.

[18] Soil Survey Staff, 2009. Soil Survey Field and Laboratory Methods Manual. Soil Survey Investigations Report No. 51, Ver. 1.0. P. 1:405, Ed. R. Burt. U.S. Dep. of Agri., Nat. Res. Cons. Ser., Lincoln, Nebraska.

[19] Staff, S.S. 2017. Soil survey manual, Eds. C. Ditzler, K. Scheffe, and H.C. Monger. USDA Handbook 18., 603 pp., Government Printing Office, Washington, D.C., USA.

[20] Stiles, C.A., C.I. Mora, and S.G. Driese, 2003. Pedogenic processes and domain boundaries in a Vertisol climosequence: evidence from titanium and zirconium distribution and morphology. Geoderma, 116(3-4): 279-299.

[21] Taboada, T., A.M. Cortizas, C. García, and E. García-Rodeja, 2006. Particle-size fractionation of titanium and zirconium during weathering and pedogenesis of granitic rocks in NW Spain. Geoderma, 131(1-2):218-236.

[22] USDA, 2014. Keys to soil taxonomy. Soil Surv. Man. Soil. Sci. Div. Staff. H.B.No. 18,Washingt, USA.

[23] Yousef, A.F. 2013. Lights on the hydrogeology of Moghra Oasis, North Western Desert, Egypt. Annals Geol. Surv. Egypt, Vol. (XXXII): 1-24.

[24] Yousf, A.F., M.A. El Fakharany, U.A.A. Risha, M.M. Afifi, M.A. Al Sayyad, 2018. Contributions to the geology of Moghra-Qattara area, North Western Desert, Egypt. J. of Basic and Environ. Sci. (5):1-19.

[25] Reid, H.M., 2013. Introduction to Statistics: Fundamental Concepts and Procedures of Data Analysis. SAGE Publications, USA, $632 \mathrm{p}$. 



\section{AMERICAN-EURASIAN JOURNAL OF SUSTAINABLE AGRICULTURE}

ISSN: 1995-0748, EISSN: 1998-1074

2019, volume (13), issue (3): pages $(10-20)$

DOI: 10.22587/aejsa.2019.13.3.2

Published Online in September http://www.aensiweb.com/AEJSA/

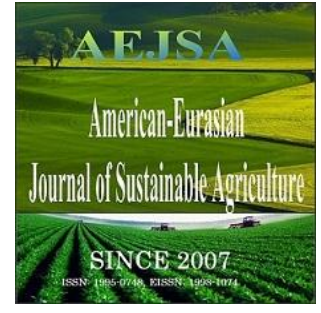

Table 5: Frequency distribution of the main groups of heavy minerals $(0.125-0.063 \mathrm{~mm})$ in the sand fraction of the south-east portion of El-Qattara depression

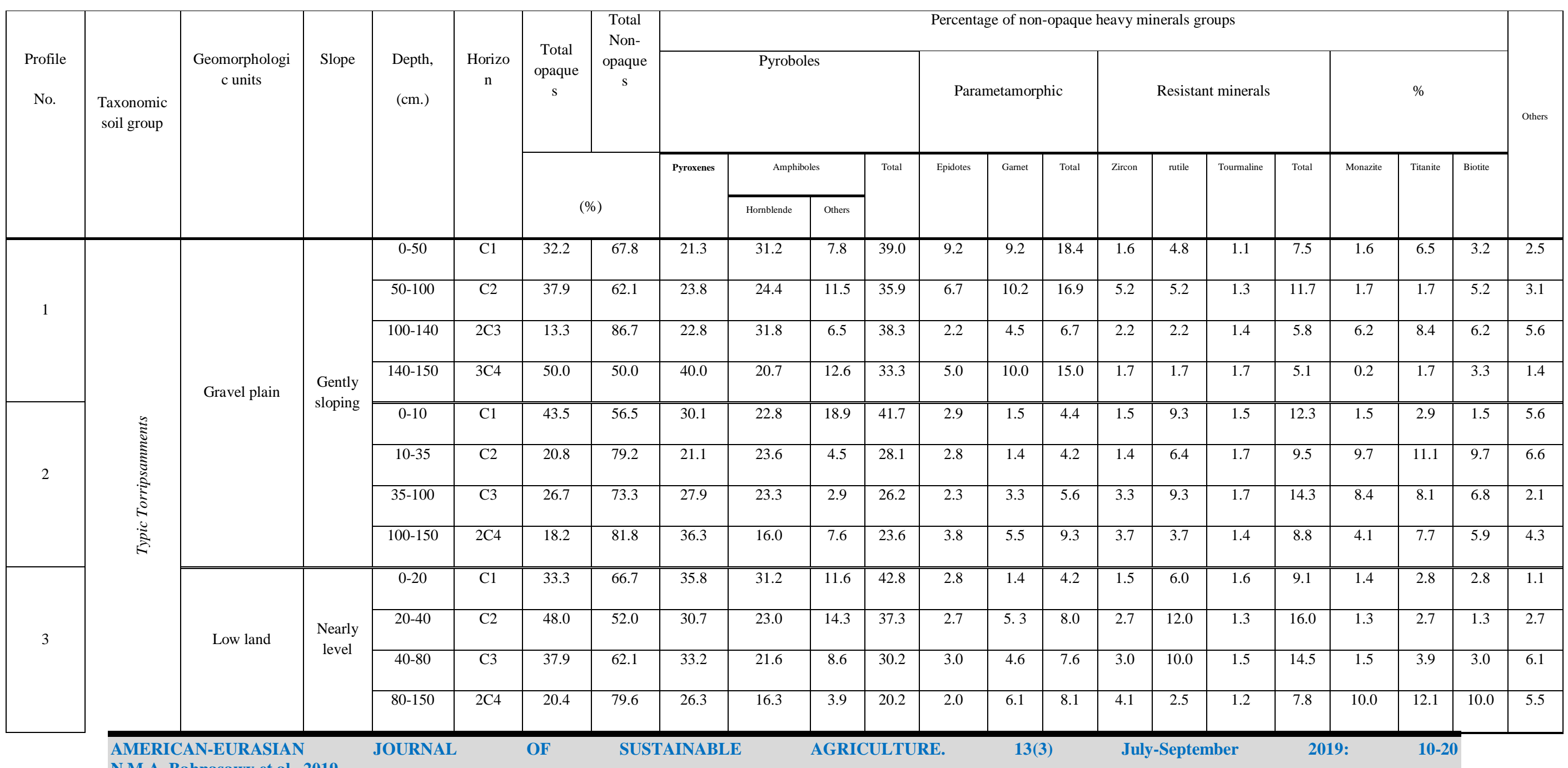

N.M.A. Bahnasawy et al., 2019 
N.M.A. Bahnasawy et al., 2019. Mineralo-chemical study of Titanium and Zirconium as indicators for soil profile uniformity and development. American-Eurasian Journal of Sustainable Agriculture. 13(3): 10-20. DOI: 10.22587/aejsa.2019.13.3.2

\begin{tabular}{|c|c|c|c|c|c|c|c|c|c|c|c|c|c|c|c|c|c|c|c|c|c|c|}
\hline \multirow{4}{*}{$\begin{array}{l}\text { Profile } \\
\text { No. }\end{array}$} & \multirow{4}{*}{$\begin{array}{l}\text { Taxonomic } \\
\text { soil group }\end{array}$} & \multirow{4}{*}{$\begin{array}{c}\text { Geomorphologic } \\
\text { units }\end{array}$} & \multirow{4}{*}{ Slope } & \multirow{4}{*}{$\begin{array}{l}\text { Depth, } \\
(\mathrm{cm} .)\end{array}$} & \multirow{4}{*}{ Horizon } & \multirow{4}{*}{$\begin{array}{c}\text { Total } \\
\text { opaques }\end{array}$} & \multirow{4}{*}{$\begin{array}{c}\text { Total } \\
\text { Non- } \\
\text { opaques }\end{array}$} & \multicolumn{14}{|c|}{ Percentage of non-opaque heavy minerals groups } & \multirow{4}{*}{ Others } \\
\hline & & & & & & & & & Pyrobo & & & Par & netamo & & & Resist & $t$ minerals & & & $\%$ & & \\
\hline & & & & & & & & \multirow[t]{2}{*}{ Pyroxenes } & \multicolumn{2}{|c|}{ Amphiboles } & \multirow[t]{2}{*}{ Total } & \multirow[t]{2}{*}{ Epidotes } & \multirow[t]{2}{*}{ Garnet } & \multirow[t]{2}{*}{ Total } & \multirow[t]{2}{*}{ Zircon } & \multirow[t]{2}{*}{ rutile } & \multirow[t]{2}{*}{ Tourmaline } & \multirow[t]{2}{*}{ Total } & \multirow[t]{2}{*}{ Monazite } & \multirow[t]{2}{*}{ Titanite } & \multirow[t]{2}{*}{ Biotite } & \\
\hline & & & & & & & & & Hornblende & Others & & & & & & & & & & & & \\
\hline \multirow{4}{*}{4} & \multirow{8}{*}{ 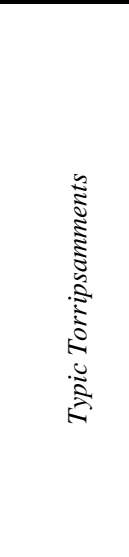 } & \multirow{8}{*}{ Low land } & \multirow{8}{*}{$\begin{array}{l}\text { Nearly } \\
\text { level }\end{array}$} & $0-30$ & $\mathrm{C} 1$ & 36.2 & 63.8 & 35.3 & 19.5 & 11.4 & 30.9 & 4.4 & 2.9 & 7.3 & 1.5 & 9.1 & 1.5 & 12.1 & 1.5 & 4.3 & 2.9 & 5.7 \\
\hline & & & & $30-80$ & $\mathrm{C} 2$ & 41.7 & 58.3 & 40.0 & 22.2 & 14.5 & 36.7 & 3.3 & 1.7 & 5.0 & 3.3 & 5.0 & 1.4 & 9.7 & 1.7 & 3.3 & 1.7 & 1.9 \\
\hline & & & & $80-120$ & C3 & 44.1 & 55.9 & 31.8 & 22.2 & 12.5 & 34.7 & 1.5 & 8.8 & 10.3 & 5.9 & 7.5 & 1.5 & 14.9 & 1.4 & 3.0 & 2.9 & 1.0 \\
\hline & & & & $120-150$ & $2 \mathrm{C} 4$ & 25.0 & 75.0 & 26.7 & 18.8 & 16.2 & 35.0 & 1.7 & 1.7 & 3.4 & 1.7 & 10.0 & 1.7 & 13.4 & 5.7 & 9.0 & 4.0 & 2.8 \\
\hline \multirow{4}{*}{5} & & & & $0-20$ & $\mathrm{C} 1$ & 32.3 & 67.7 & 22.9 & 18.6 & 99.1 & 27.7 & $\begin{array}{ll}10.8 \\
\end{array}$ & 7.6 & 18.4 & 1.6 & 44.9 & 1.9 & 88.4 & 1.6 & 8.1 & $\begin{array}{l}4.8 \\
\end{array}$ & 8.1 \\
\hline & & & & $20-60$ & $\mathrm{C} 2$ & 38.5 & 61.5 & 38.1 & 14.3 & 8.4 & 22.7 & 4.5 & 4.5 & 9.0 & 1.6 & 1.6 & 1.8 & 5.0 & 6.4 & 6.4 & 6.4 & 6.0 \\
\hline & & & & $60-100$ & C3 & 47.6 & 52.4 & 39.1 & 16.2 & 13.3 & 29.5 & 3.2 & 7.6 & 10.8 & 1.6 & 9.2 & 1.7 & 12.5 & 0.4 & 4.8 & 1.6 & 1.3 \\
\hline & & & & $100-150$ & $2 \mathrm{C} 4$ & 44.6 & 55.4 & 32.5 & 23.2 & 7.5 & 30.7 & 5.6 & 9.0 & 14.6 & 3.6 & 7.8 & 1.6 & 13.0 & 1.8 & 3.6 & 1.8 & 2.0 \\
\hline
\end{tabular}

